Meta

Journal des traducteurs

Translators' Journal

\title{
The Indicative Power of A Key Word System. A Quantitative Analysis of the Key Words in the Translation Studies Bibliography
}

\section{Luc Van Doorslaer}

Volume 50, numéro 4, décembre 2005

Pour une traductologie proactive - Actes

For a Proactive Translatology — Proceedings

Por una traductología proactiva - Actas

URI : https://id.erudit.org/iderudit/019858ar

DOI : https://doi.org/10.7202/019858ar

Aller au sommaire du numéro

Éditeur(s)

Les Presses de l'Université de Montréal

ISSN

0026-0452 (imprimé)

1492-1421 (numérique)

Découvrir la revue

Citer cet article

Van Doorslaer, L. (2005). The Indicative Power of A Key Word System. A

Quantitative Analysis of the Key Words in the Translation Studies Bibliography.

Meta, 50(4). https://doi.org/10.7202/019858ar

\section{Résumé de l'article}

Dans son évolution des dernières décennies, la traductologie se veut explicitement interdisciplinaire, ce qui a permis à cette discipline - encore toute jeune - d'élargir son domaine de recherches. Mais cette tendance a également mené à un éclectisme dans les sujets traités, les méthodes appliquées, les influences subies. Comme toute discipline jeune à la recherche de reconnaissance, la traductologie a dirigé ses recherches vers des intérêts et des domaines communs à d'autres sciences déjà établies. Ceci s'est cependant souvent fait avec (trop) d'ambition et de façon (trop) peu structurée.

Pour l'analyse de la diversité des influences, nous nous sommes basé sur les résultats obtenus grâce à la Translation Studies Bibliography (TSB — lancée pour la première fois en octobre 2004). Cette nouvelle base de données bibliographiques en ligne (mise à jour annuellement (au mois) regroupe les publications de la dernière décennie. Elle offre plus de 7000 entrées annotées que l'utilisateur peut consulter grâce à un système de mots-clé sophistiqué. L'analyse quantitative de ces mots-clé aussi bien que de leurs champs thématiques nous donne d'importantes indications quant aux priorités de recherche dans le domaine de la traductologie de la dernière décennie. Quel est, proportionnellement parlant, le rapport entre les recherches faites en traduction et celles faites en interprétation? La recherche en traduction littéraire est-elle toujours aussi répandue que dans les années 1980 ? Quelles relations les publications sur le 'cultural turn' et sur le 'power turn' entretiennent-elles?
Ce document est protégé par la loi sur le droit d'auteur. L'utilisation des services d'Érudit (y compris la reproduction) est assujettie à sa politique d'utilisation que vous pouvez consulter en ligne.

https://apropos.erudit.org/fr/usagers/politique-dutilisation/ 


\title{
The Indicative Power of A Key Word System. A Quantitative Analysis of the Key Words in the Translation Studies Bibliography
}

\author{
LUC VAN DOORSLAER \\ Lessius Hogeschool, Antwerp, Belgium \\ University of Leuven, Leuven, Belgium \\ luc.vandoorslaer@lessius-ho.be
}

\begin{abstract}
RÉSUMÉ
Dans son évolution des dernières décennies, la traductologie se veut explicitement interdisciplinaire, ce qui a permis à cette discipline - encore toute jeune - d'élargir son domaine de recherches. Mais cette tendance a également mené à un éclectisme dans les sujets traités, les méthodes appliquées, les influences subies. Comme toute discipline jeune à la recherche de reconnaissance, la traductologie a dirigé ses recherches vers des intérêts et des domaines communs à d'autres sciences déjà établies. Ceci s'est cependant souvent fait avec (trop) d'ambition et de façon (trop) peu structurée.

Pour l'analyse de la diversité des influences, nous nous sommes basé sur les résultats obtenus grâce à la Translation Studies Bibliography (TSB - lancée pour la première fois en octobre 2004). Cette nouvelle base de données bibliographiques en ligne (mise à jour annuellement (au mois) regroupe les publications de la dernière décennie. Elle offre plus de 7000 entrées annotées que l'utilisateur peut consulter grâce à un système de mots-clé sophistiqué. L'analyse quantitative de ces mots-clé aussi bien que de leurs champs thématiques nous donne d'importantes indications quant aux priorités de recherche dans le domaine de la traductologie de la dernière décennie. Quel est, proportionnellement parlant, le rapport entre les recherches faites en traduction et celles faites en interprétation? La recherche en traduction littéraire est-elle toujours aussi répandue que dans les années 1980 ? Quelles relations les publications sur le 'cultural turn' et sur le 'power turn' entretiennent-elles ?
\end{abstract}

\begin{abstract}
Over the last decades, Translation Studies has explicitly tried to develop and regard itself as an interdiscipline. This evolution, as well as this self-esteem, has not only widened the focus of the field, it has also created a sometimes unclear eclecticism of topics, influences and methods. Characteristic of a still not too well-established and not always acknowledged discipline, research in Translation Studies has been looking for common interests and common grounds with other disciplines in an ambitious, but often unstructured way.

The new online Translation Studies Bibliography (TSB - first release October 2004), which concentrates on the last decade, is used here as a tool for the analysis of the multiplicity of influences. Expanded several times a year, the TSB offers more than 7,000 annotated entries and uses a sophisticated key word system. The quantitative analysis of these key words and their thematic fields indicate the priorities in the dissemination of TS research over the past decade. How does research on translation today reflect this assumption? Is research on literary translation still as widespread as it was in the eighties? What is the relationship between publications on the 'cultural turn' and those on the 'power turn'? The results of this analysis may indicate emphases and research priorities for the next decade in Translation Studies.
\end{abstract}

MOTS-CLÉS/KEYWORDS

bibliography, key words, quantitative analysis, cultural turn, power turn

Judging by the number of invitations translation receive scholars nowadays for conferences worldwide, for contributions to monographs, or special issues of translation studies journals, it 
would appear that we belong to a wonderful and flourishing discipline. But is it merely a subjective impression that in this discipline there is also a considerable amount of overlap, that the same topics are often treated in perhaps a slightly different fashion,that some topics may be quite fashionable, and perhaps not convincing enough to hold the focus of our academic and professional interest in the long term?

What scholars can still claim is that they have a clear overview of all possible influences, subdisciplines and ambitions of the field of translation studies (also called: translatology),a field that has explicitly called itself an interdiscipline, which has of course widened the scope of the field, but that has also created an unclear eclecticism of topics, methods and influences. In some discussions in journals over the past years, scholars have been looking for common interests and common grounds in this fragmenting evolution (e.g. explicitly in Chesterman and Arrojo 2000 and several reactions in a forum discussion and the concluding articles Arrojo 2002 and Chesterman 2002). In this article, I compare my own findings with those of some publications describing and evaluating recent developments and the state of the art of the discipline. It is an attempt to add some 'objective' elements to that vital and necessary discussion. I will refer to a tool that furnishes recent data that is both solid and reliable: the current online Translation Studies Bibliography or TSB (see Gambier and van Doorslaer 2004). I believe this annotated bibliography (with abstracts and key words for all entries) is a useful tool for my analysis because of several reasons. First of all, the TSB mainly focuses on the last decade of Translation Studies (1994-2004). It is therefore appropriate for analysing recent trends. Secondly, at present the TSB database contains about 7,000 entries, which makes it a representative and solid quantitative basis. In addition, the TSB is structured to indicate categories in the discipline as well as their interrelationships. It provides key words and organizes them in hierarchical as well as thematic networks. I have used the more than 600 TSB keywords for a small quantitative analysis. Since the corpus examined deals with publications over the last decade in translation studies, it offers relevant information about the topics the discipline has been dealing with over this period. First we should indicate the degree of relevance of the figures. Since about ten percent of the key words occur more than 100 times, we should consider this frequency as "high" and certainly "relevant".

A first basic distinction is to be made between translation and interpreting. As can be expected, much less is published on interpreting. If we add up the different key words that deal with kinds of interpretation (community interpreting, conference interpreting, consecutive interpreting, simultaneous interpreting, court interpreting, interpreter training), there are about 700 publications on interpreting in the TSB, which means around ten percent.

In the category of key words dealing with methodology or research approaches, the most frequent is 'comparative research' (393), followed by 'case study' (365, often linked with descriptive research), 'corpus' (228) and 'empirical research' (206). This category shows us very clearly that these key words are not exclusive by nature. For instance, an entry could combine a case study with empirical research. Nevertheless these figures suggest existing power relationships, in particular concerning comparative research in Translation Studies as well as for "the growing empirical orientation of the discipline" (Delabastita 2003: 13).

This indication of power relationships is also valid for the two main directions that have dominantly influenced Translation Studies until now: linguistics and literary studies.

While cultures and languages seem inseparable, cultural and linguistic approaches in Translation Studies have, paradoxically, been antagonistic. From the beginning, Translation Studies has been influenced from two main directions: linguistics and literary studies, the latter developing towards a cultural studies perspective. The representatives of the two traditions have tended to view each other with mutual distrust. (Koskinen 2004: 145).

The famous cultural turn in Translation Studies undoubtedly has taken place. The key words 'linguistics' and 'linguistic approach' can be found 260 times, on the other hand 'culture' and 'cultural studies' appear about 560 times. But of course we have to put these findings into 
perspective. Partial linguistic approaches can also be found in publications dealing with (the key words) grammar, phonetics, semantics, stylistics etc. Still, when Koskinen (2004:150) observes that the cultural studies approach "entered Translation Studies as a tactical move, as a tool to redirect theoretical discussion. It was a negation, an anti-concept, defined by what it was not: culture as antilanguage; the cultural paradigm as anti-linguistic," we have to conclude that the tactical move of the cultural paradigm, at least from a quantitative point of view, has succeeded.

Attention should also be paid to recent developments in research on the 'committed' cultural approaches in Translation Studies. Koskinen suggests bringing these new postmodern perspectives (dealing with ethics, ideology, feminism, postcolonialism, deconstruction etc.) together under the general title of 'Critical Translation Studies' (2004: 153). And in line with the terminological tradition of Translation Studies, Maria Tymoczko and Edwin Gentzler have already introduced the concept of 'power turn' in our discipline.

[...] given that we are always already formed by the discourses of the age in which we live, how can anyone effect cultural change? How can we bridge cultural gaps so as to experience anything new or different? [...] What sort of impact does translation have on cultural change? Under what circumstances do translations have most impact? What forms of translation are most successful? And how does all this relate to cultural dominance, cultural assertion, cultural resistance - in short to power? In a sense, such questions as these have meant that the 'cultural turn' in translation studies has become the 'power turn', with questions of power brought to the fore in discussions of both translation history and strategies for translation (Tymoczko and Gentzler 2002: xvi).

In the publications of the last decade as covered by the TSB, the ,power turn' is undeniably present. In my analysis of the TSB database, the postcolonialist approach appeared in the annotations of exactly 100 entries. 'Ideology' had 165 hits, ethics 93, '(critical) discourse analysis' 50, and 'gender studies' 43.

Another category is that of the different types of discourse represented in the TSB key word system. When using discourse here, I mean the kinds of text that have been translated, of them 522 entries explicitly deal with the translation of literary discourse. Other results are as follows:

Legal discourse

Technical discourse

Religious discourse

Political discourse

Scientific discourse

Medical discourse

Economic discourse

\section{0 hits}

195

134

132

115

108

93

When we cluster all these types of non-literary discourse, we count 1,007 entries, which is almost twice the number of entries dealing with literary discourse. At conferences, it is often claimed that research in translation studies traditionally focuses too much on literature. These quantitative findings refute such claims. Publications on the translation of non-literary texts seem to have clearly gained the upper hand in the last decade.

It is worth noting that some traditional or classical terms occur very frequently in the TSB key words are still quite popular: equivalence (237 hits), faithfulness/fidelity (140) and (un)translatability (130). Of course the mere presence of these terms is not indicative of the quality or evolution of their usage. In some cases publications explicitly focus on the changing content of these traditionally very frequently used concepts.

Besides the articles by Delabastita and Koskinen dealing with the state of the art and new tendencies in translation studies, there was a contribution with a similar purpose published by Wolfram Wilss last year in Meta (Wilss 2004). In this article, Wilss describes the ongoing evolution of the discipline and highlights some areas of research that, according to him, will play a leading role in the near future of translation studies. A role that has clearly already begun, judging by the number of publications on these topics already present in the TSB: 
Computer/machine translation312 hits

Translation process 282

Thinking-Aloud Protocols 127

Another field highlighted by Wilss is certainly not new, but still an area many publications deal with. By adding up the key words 'teaching', 'training', 'curriculum' and 'evaluation', the umbrella concept of 'translation didactics' appears in around 1200 TSB entries. Thus, it should be considered one of the most important subfields in translation studies, at least from a quantitative point of view. Many scholars and researchers are also involved in translation teaching and publish articles about that practical aspect, or about the tension between the applied and non-applied aspects in the field.

This is a cursory analysis of a small part of the 600 TSB key words. In-depth analysis and qualitative clarification and differentiation are desirable. Still, it is based on reliable data and a corpus of many thousands of publications in translation studies, and therefore gives an idea about the directions in which the discipline is headed. The strong presence of contributions on the didactics of translation illustrates one trend: the pursuit of traditional topics but with different emphases and approaches. On the other hand, there is diversity through the development of new areas and subdisciplines, multiple topics, methods and influences. This is evidence that translation studies is thriving, although it sometimes goes off course. Some existing power relationships, as I have tried to point them out, may look very different in five years or so. Such is the inevitable consequence of the differentiation of a discipline as echoed by Wilss.

TS research is now directed towards a multitude of targets and, as a result, research priorities are constantly shifting. In response to this development, TS research has turned away, at least to a large extent, from 'topdown' (theoretical) towards 'bottom-up' (empirical/applied) research. [...] There is now a strong belief that a wide spectre of TS activities is indispensable for solving problems which are far beyond the traditional array of subject-matters (Wilss 2004: 780-781).

\section{REFERENCES}

Arrojo, R. (2002): “Lessons learned from Babel”, Target 14-1, pp. 137-143.

Chesterman, A. (2002): "Shared ground revisited", Target 14-1, pp. 143-148.

Chesterman, A. and R. Arrojo (2000): "Shared ground in Translation Studies", Target 12-1, pp. 151-160.

DelabastiTA, D. (2003): "Translation Studies for the 21st century: Trends and perspectives", Génesis. Revista científica do ISAI 3, p. 7-24.

GAMBIER, Y. and L. VAN DOORSLAER (eds.) (2004): Translation Studies Bibliography (first release), Current online bibliography with several updates a year, Amsterdam/Philadelphia, John Benjamins, Appr. 7500 entries (May 2005), <www.benjamins.nl/online/tsb $>$.

Koskinen, K. (2004): "Shared culture? Reflections on recent trends in Translation Studies", Target 16-1, pp. 143156.

TyMoczko, M. and E. Gentzler (2002): "Introduction”, in TyMoczKo, M. and E. GentZler (eds), Translation and Power, Amherst/Boston, University of Massachusetts Press, pp. i-xxviii.

WILSS, Wolfram (2004): “Translation Studies - The State of the Art”, Meta 49-4, pp. 777-785. 